\title{
SIMILARITIES AND DIFFERENCES BETWEEN \\ VIETNAMESE CULTURE AND LAO CULTURE \\ THROUGH THE MOTIF OF BUILDING ORPHAN \\ CHARACTERS IN THE MAGICAL FAIRY TALES OF \\ TAM AND CAM AND THE GOLDEN TURTLE
}

\section{SIMILITUDES Y DIFERENCIAS ENTRE LA CULTURA VIETNAMITA Y LA CULTURA LAO A TRAVÉS DEL MOTIVO DE CONSTRUIR PERSONAJES HUÉRFANOS EN LOS MÁGICOS CUENTOS DE HADAS DE TAM Y CAM Y LA TORTUGA DE ORO}

\author{
Le Thi Bich Thuy ${ }^{1}$ (iD). \\ 1. Institute for Culture and Development, Ho Chi Minh National Academy of Politics, 135 Nguyen Phong Sac Street, \\ Cau Giay District, Hanoi, Vietnam. lebichthuyhcma@gmail.com \\ *Correspondencia del Autor: Le Thi Bich Thuy, correo electrónico: lebichthuyhcma@gmail.com.
}

\begin{abstract}
Sharing the sources of Southeast Asian folklore and folk literature, magical fairy tales of Vietnam and Laos have many similarities in a motif of building orphan characters. Applying structural theory in fairy tales with immutability and changes, the structure of the story is described by a series of events "signs help to make a schematic comparison of the structure of various tales," (Propp, 1968, p.25) the article studies the magical fairy tale Tam and Cam of Vietnam and the Golden Turtle of Laos to see the similarities and differences in the motif of building orphan characters. The similarities in the motif of building orphan characters such as: story structure, character system, incarnation motif, unique object motif, magical force motif show the common cultural space of the region. However, the difference in the situation of the story and the use of magical forces and elements in the story show the customs, belief characteristics, artistic tastes and cultural identity of each nation.
\end{abstract}

Keywords: Orphan character motif; magical fairy tales; Tam and Cam; the Golden Turtle; Vietnam; Laos.

Cómo citar:

Le Thi Bich Thuy. (2020). Similarities and differences between vietnamese culture and lao culture through the motif of building orphan characters in the magical fairy tales of tam and cam and the golden turtle. Revista de Investigaciones Universidad del Quindio, 32(2), 102-114. https://doi. org/10.33975/riuq.vol32n2.460

Información del artículo: Recibido: 15 noviembre 2020; Aceptado: 28 diciembre 2020 


\section{RESUMEN}

Compartiendo las fuentes del folclore y la literatura popular del sudeste asiático, los cuentos de hadas mágicos de Vietnam y Laos tienen muchas similitudes en el motivo de la construcción de personajes huérfanos. Aplicando la teoría estructural en los cuentos de hadas con inmutabilidad y cambios, la estructura de la historia se describe mediante una serie de eventos "los signos ayudan a hacer una comparación esquemática de la estructura de varios cuentos" (Propp, 1968, p.25) el artículo estudia el mágico cuento de hadas Tam y Cam de Vietnam y la tortuga dorada de Laos para ver las similitudes y diferencias en el motivo de la construcción de personajes huérfanos. Las similitudes en el motivo de la construcción de personajes huérfanos tales como: estructura de la historia, sistema de personajes, motivo de encarnación, motivo de objeto único, motivo de fuerza mágica muestran el espacio común cultural de la región. Sin embargo, la diferencia en la situación de la historia y el uso de fuerzas y elementos mágicos en la historia muestran las costumbres, las características de las creencias, los gustos artísticos y la identidad cultural de cada nación.

Palabras clave: Motivo de personaje huérfano; mágicos cuentos de hadas; Tam y Cam; la tortuga dorada; Vietnam; Laos.

\section{INTRODUCTION}

Living in the same geographical area, the inhabitants of Southeast Asia creates an indigenous cultural unity with common roots from prehistoric and early history. In the common cultural space of the region, there is a diversity of cultural colors. Because, each culture has its own origin and identity, changing throughout history. "Southeast Asian culture is a sedimentary process of the cultures of the region, of the world and the process of changing the space, time, environment of these sedimentary layers has been localized into a unique cultural product of each nation and the whole of Southeast Asia." (Duc, 1999, p. 16). Vietnam and Laos are two countries of Southeast Asian culture, sharing the same cultural environment space as the traditional cultural space formed (Nguyen, 1993) and developed on the basis of indigenous culture (wet rice agriculture civilization) and the process of acculturation outside the region (Ngo, 1995, p. 37). In the development process of Southeast Asian literature in general and literature of Vietnam and Laos in particular, folk literature flourishes, develops and "folk literature is considered the source of Southeast Asian regional literature and this is also the indigenous cultural layer before Southeast Asia was influenced by large cultures from outside. Folklore dominates, stands out and covers the entire literary process of Southeast Asia" (Duc, 1999, p. 27).

In the treasure of folk literature, fairy tales develop richly and dominate. "the traditional tale provides something like the skeletal structure of the plot, and the author fleshes that structure out to present a theme that may or may not have been implicit in the original" (Sullivan, 2001, p. 284). In it, the plot and the character system in fairy tales play an important role in reflecting and explaining conflicts and contradictions in social life and human fate. Therefore, the historians, philosophers, literary researchers and their characters usually absorb from the treasure of collective wisdom and they are often talked about as things that everyone knows (Lisevich, 1978, p. 249). The orphan character in fairy tale is formed in the old society, the old family and associated with primitive rites and religions (Propp, 1968). Orphaned children are one of the most miserable people who have to accept the whole misfortune of life, motherless orphan - An intensified form of absentation is represented by the death of 
Parents, (Propp, 1968) live with stepmother and be exploited and oppressed in all aspects. At this time, folk authors who are miserable in society sympathize, protect and help them with magical elements. The image of an orphan character in a fairy tale is the first socially based image of folk literature, an image without mystical mythology. The widespread popularity of the image of an orphan is the inevitable result of the disintegration of matriarchy. The unfortunate orphan becomes a typical historical product. The appearance of the orphan image marks the birth of a magical fairy tale as a genre (Meletinsky, 2000). Based on the classification of fairy tales and the generalization of the characteristics of magical fairy tales, the researcher believes that the image of orphan characters is an important topic in the system of magical fairy tales.

Located in the common flow of treasure of folk literature of mankind, magical fairy tales of Vietnam and Laos also bring many similarities in structure and motif of building character (Propp, 1968, p. 21-23). The image of an orphan character becomes a prominent figure in the magical fairy tales of Vietnam and Laos, both having universal features and having its own characteristics that show the specific characteristics of each nation. In the study of The similarities and differences in some types of Lao and Vietnamese folk tales, the author points out the similarities and differences of three types of stories: the hero story, the unfortunate people story and the man in animal shape (Lai, 2004). Plot and art motif of the fairy tale of Tam and Cam of Vietnam have similarities and differences from the fairy tales of countries in Southeast Asia (Dinh, 1968). Fairy tales about the orphan character in the Lao folklore treasures have many similarities with Vietnamese fairy tales such as the Golden Turtle of Laos and the Tam and Cam of Vietnam (Dao, 1986). However, the magical plot and motif of these magical fairy tales also have differences and reflect the local living conditions and cultures of each country (Que, 1985).

Magical fairy tales of Vietnam are stories imaging the life of a certain type of character, including the unfortunate character type, "the central characters of fairy tales are the humble people in the class society such as orphans, stepchildren, and youngest brothers" (Tang, 1994, p. 25). "The orphan is the third most popular character in social fairy tales" (Cao, 1974). The humble characters in magical fairy tales are the first social characters (Nguyen, 1998). The vile characters in magical fairy tales are the first social characters. In the magical fairy tale of Tam and Cam "the main topic of this type of story is the conflict between the stepmother and her husband's children, that is, the type of family conflict, which occupies an important position in magical fairy tales" (Le, 2001, p. 122). When studying the genre of fairytale in Lao literature, researchers point out the contradictions in the magical fairy tales, mainly contradictions between social conflict and family conflict. In particular, social conflict is between small people, typically orphan characters with patriarchs, family conflict often takes place between stepchild and stepmother, eldest brother and youngest brother, and the sister-in-law and her brother-in-law (Duc, 1999). In the Lao folklore treasure, the orphan character is a prominent artistic figure and prevails in the fairytale, "the story of children abandoned by parents, orphans and stepchildren" (Tuyet, 1981, p. 11). Studying the role of the weak characters in fairy tales, the researchers emphasize: "Laos has many fairy tales with the main character of a poor orphan" (Nguyen, 2005, p. 18). The orphan character in fairy tales is the character that left a deep impression on everyone, "the number of Lao fairy tales with orphan characters accounts for a relatively high percentage" (Luu, 1989).

Thus, the above research works initially mention the similarities and differences in some folktales between Vietnam and Laos. At the same time, the researchers make some general comments about the similarity of orphan character motif in magical fairy tales and give illustrative examples such as the Golden Turtle of Laos and the Tam and Cam of Vietnam. The research comparing motif of building the image of orphan characters 
in the fairy tales of Vietnam and Laos has not been paid much attention by researchers. In a number of research works on folklore genre of each country, the researchers just stop at the initial general comments on the similarities in the magical fairy tales whose central character is the orphan character. However, there has not been any in-depth research project that analyzes the main relationships in fairy tales and compares the similarities and differences of the motif of building orphan characters in magical fairy tales of Vietnam, Laos and motif of building orphan characters in the magical fairy tales of Tam and Cam and the Golden Turtle.

\section{METHODS}

The magical fairy tale of Tam and Cam of Vietnam and the Golden Turtle of Laos are fairy tales about the motherless child, the story contains elements of immutability and change, the structure of the story is described by a series of events (Propp, 1968). This article uses the text analysis method (Nguyen, 2006) and the comparative method "as a manipulation of thought, comparing literature as a research method" (nguyen, 2011, p. 60), the method of "studying the commonalities between phenomena to prove the similarities between the literature of nations" (Nguyen, 2011, p. 112) to see the similarities of the motif of building orphan characters in magical fairy tales of Vietnam and Laos. At the same time, the article also highlights the difference in the motif of building orphan characters that is unique characteristics in the cultural picture of each nation.

\section{RESULTS}

Fairy tales are born when the original communist regime is disintegrated and replaced by a private ownership regime and family form with the appearance of new conflicts. The new historical conditions change the relationships, classes and magical fairy tales reflect the realities of human society. These are contradictions in the family, clan and later extended to the village and society. Orphan characters are also placed in those relationships. In the shared flow of folklore treasures, the image of an orphan character becomes a prominent figure in the magical fairy tales of Vietnam and Laos. The image of this character is universal showing the convergence of folklore and at the same time, it has its own characteristics showing the peculiarities of each nation. Survey of the magical fairy tales of Tam and Cam of Vietnam and the Golden Turtle of Laos shows similarities in the character system, incarnation motif, unique object motif, magical force motif and the differences in the magic element in building the image of orphan character.

\section{Similarities between Vietnamese culture and Lao culture through the motif of building orphan characters in the magical fairy tales}

\section{Similarities in structure of story}

The magical fairy tales of Tam and Cam and the Golden Turtle have the same structure: The character is motherless and has to live with stepmother - The villain employs other means of deception or coercion (q3), the core function of the tale 'villainy', create its possibility of occurence, or simply facilitate its happening. Complication in the tale begun by an act of villainy (Propp, 1968, p. 31). The villain plunders in other forms (A5) and the villain causes bodily injury (A6). The stepmother always seeks to torment the orphan character, who is always appropriated the fruit of labor by her evil sisters counting on their mother's power (stepmother) to be lazy. The orphan character has to overcome difficulties and challenges and thanks to his inherent good quality with the will, the resilience and the strong support of the magical force, she can overcome difficulties, dangers and marry a rich husband. (Propp, 1968, p. 35) However, the miraculous fairy tales of Tam and Cam and the Golden Turtle do not end at the fact that the girls marry a worthy husband and have a happy life. In the happy life after getting married, the orphan character is always filial to her father, stepmother and younger sister but continues to be murdered by stepmother. The orphan character 
is saved by the miracle after many incarnations in many different forms to her husband, regain happiness and those who cause the crimes are properly punished. Incarnation motif of the orphan character in magical fairy tales shows the persistent struggle between good and evil. This is the cultural characteristic of the miraculous fairy tales of Vietnam and Laos. In the story of Tam and Cam, the character Tam is the daughter of the first wife and Cam is the daughter of the second wife. Tam is a gentle and hard-working person, but she often gets cheated and harmed by Cam and her mother. Once, when she goes to catch shrimp, Tam is cheated by Cam to take away all shrimp, there is only a goby, and she brings the goby back to breed in the well, loves and cares for it, but then Cam and her mother kill the goby for eating. During a festival, a Buddha appears to help Tam and gives her nice clothes and shoes. Then, Tam drops the shoe, the king picks it up and find the owner of the shoe, and Tam becomes queen. On her father's death anniversary, Tam is killed by her stepmother and she takes Cam to the palace to replace Tam. After death, Tam turns into Oriole, Bead tree, Loom, Thi fruit and undergoes many difficulties and challenges, the king recognizes her thanks to the phoenixwinged betel nut because she is very skillful. She returns to the palace as a queen, lives happily with the king and the stepmother and her daughter is properly punished (Nguyen, 1975). In the story the Golden Turtle, Chan Tha is the daughter of the first wife and Chan Thi is the daughter of the second wife. Chan Tha lives in an orphaned and humiliated situation, abused by stepmother both physically and mentally. When Chan Tha's mother dies, she turns into a golden turtle to give her the fragrance. Her stepmother knows that, so she tortures Chan Tha and forces her to cook golden turtles. Chan Tha collects the golden turtle's bones and buries them at a crossroads, then a green Bodhi trees producing music grows. The Bodhi tree helps Chan Tha become a queen, but upon hearing that her father is sick, she visits her father and is harmed by her stepmother, her stepmother brings Chan Thi into the palace to replace Chan Tha. After death, Chan Tha turns into a Mactum fruit in the royal garden, which is brought home by the old lady. On one occasion, when the king sees the betel nut shaped by Chan Tha, he recognizes her and welcomes her into the palace, her father, stepmother and her daughter are properly punished (Tuyet, 1981).

The fairy tales of Tam and Cam and the Golden Turtle reflect the contradictions and conflicts in the family between stepmother and stepchild and social meaning is the conflict between Good and Evil. "The topic of stepmother - stepchild is one of the most significant topics of intense social struggle. When the clan commune disintegrates, class in the human society is appeared along with small families. The family is patriarchal, with the private system being the cell of feudal society, with the distinction between rich - poor, luxurious - coward, and exploitation of people" (Dinh, 1968, p. 219). The characters Tam and Chan Tha are the characters representing the Good. The action of an orphan character always takes place under a motif: The motherless character is abused, the motherless character is assisted by magical forces to have happiness, the orphan character is harmed, died and turned into a new form as a tree or an animal, the orphan character after many transformations has happiness, a better life and the wicked are punished. The character stepmother represents the Evil, always trying to torture and kill her husband's stepchild to rob her husband and rich life for her daughter, she is always punished properly at the end of the story. The victory of the Good for the Evil reflects the people's dreams and aspirations for the battered and miserable people. However, with their inherent good qualities, they are compensated with fairness and happiness in life.

\section{Similarities in building character systems}

The magical fairy tales of Tam and Cam and the Golden Turtle build two opposing character systems on personality and action to reflect the fierce contradictions and conflicts in the family. One side seeks all ways to destroy the lives of little and poor people and one side seeks all ways 
to fight for survival. The orphan characters in the magical fairy tales of Tam and Cam and the Golden Turtle are gentle and pitiful people, the idealization of the people of Vietnam and Laos. The orphan characters must live in material deprivation, are always oppressed and tortured but have the beauty of the soul, the quality, the honest character and this beauty brings happiness to them in life. The similarity in building orphan characters in Vietnamese and Lao magical fairy tales is the orphan character system typical for Beauty and Good. The opposition to orphan characters is a system of villains built according to the common motif of wicked and evil people, who always find ways to exploit, oppress, and rob what the orphan character has but finally receives tragic and appropriate punishment.

Characters Tam and Chan Tha are girls who are beautiful, gentle, virtuous, hardworking and hospitable to their parents. Chan Tha in the story of the Golden Turtle is a beautiful girl, despite being buffeted and rejected by her father and stepmother but when becoming a queen and living in wealth, she always thinks about her father. When she hears that her father is ill, she is ready to visit her father. Tam in the Tam and Cam story is a beautiful, kind, honest, hardworking and loving girl. She is always abused by her stepmother, but she always can only cry and when she becomes the wife of the king, she does not forget her father's death anniversary. However, the gentle, honest people are always harmed by the hostile forces of stepmother and her daughter and sometimes they are harmed by their own father. It seems that orphan characters are born to embrace all the misfortunes of life: life of hardship, oppression, exploitation and murder. They often do works such as burning off to clear land, plowing, crabbing, catching fish, etc., all associated with the living environment of wet rice farmers in Vietnam and Laos.

The folk authors portray two opposing personalities between the orphan character (stepchild) and stepmother, younger sister. The stepmother and younger sister are characters that represent evil in society, always threatening human life. The orphan characters are idealized with nice, filial and altruistic characters and stepmother and younger sisters are evil, cruel people. Stepmother and her daughter always try to buffet, torture and harm their stepchild such as forcing the motherless character to work from dawn to dusk, only feeding leftovers, stealing the fruits of labor, extinguishing all joy and hope in life, killing stepchildren and revived lives to usurp the happy life of the motherless character. Her stepmother's actions to kill Tam and her revived lives, such as the killing of the Oriole, the chopping of the Bead tree, and burning of the loom into ashes are the ultimate symbol of the atrocities of the evil forces. These wicked people are always ready to act to destroy and fight innocent people. However, Chan Tha is more painful when she is subjected to the exile, torture and cruel acts of her stepmother and she is even harmed by her father. Chan Tha stepmother is a transfigured demon, so her actions are those of the devil, killing Chan Tha's mother and killing her incarnations, always seeking to torment, exploit and kill Chan Tha to occupy all assets. Orphan characters representing the Good and the Beauty will enjoy the happy life, while the villains representing the Evil and the Bad will be punished and have a tragic ending. This shows the aspiration of the working people of Vietnam and Laos to live a peaceful, prosperous, fair and equal life.

\section{Similarities in incarnation motif}

As the basic core of the plot, the motifs are "elements, large or small parts that are formed sustainably and used repeatedly in the creation of folklore literature" (Dinh, 1968, p. 168). In the fierce conflict between Good and Evil, the incarnation motif is an indispensable product in the uncompromising struggle of the little people and the vicious enemy forces. "Otherworld journeys showed the adventure of characters to variously fantastic and illusory worlds in folktales" (Nguyen, 2017, p. 115). The reincarnation motif is used by folk authors 
as an effective means of regaining the blessings of unfortunate characters. This motif expresses the vitality and the gradual struggle for life, the happiness of the unfortunate character. Journey to the different world in fairy tales has many different motifs: Journey to another world like dreams or visions, Journey to the higher world, Journey to the lower world, Journey to the spirit world (Thomson, 1958). The orphan characters in a magical fairy tale after being harmed, subjected to numerous injustices, are finally incarnated, revived and reunited with their family and have happy life. The transformation in the incarnation motif is a temporary element to solve the conflicts caused by the cruelty and cunning of the stepmother and her daughter who have led to the unjust death of the orphan character. When orphan characters are in danger of their lives, they are temporarily incarnated into a different world with different shapes such as gentle, lovely and human-friendly animals (the oriole in the Tam and Cam story; the golden turtle in the Golden Turtle story), the familiar and beneficial aromatic plants and fruits in life (Bead tree, Thi tree, Thi fruit in Tam and Cam story; Bodhi tree and Mactum fruit in the Golden Turtle story). These animals, plants and fruits are all familiar in life, close to people, bringing the pure nature like the holy nature of the motherless character. In the uncompromising struggle with the evil forces, the characters representing the Good have undergone many transformations with different rebirths. Tam in his uncompromising struggle with Cam and her mother in Tam and Cam story undergoes four incarnations: Tam after being killed transforms into the oriole, the Oriole after being murdered transforms into the Bead tree, the Bead tree is cut down to make a Loom, the burnt Loom grows an Thi tree and the Thi tree produces Thi fruit. The mother of Blanket Tha in the story the Golden Turtle after being killed turns into a golden turtle to daily visit her daughter. When the golden tortoise is killed, it turns into a green bodhi tree producing music. The murdered Chan Tha transforms into a Mactum fruit, a fruit that spreads a fragrance like her own being. In the motif of transforming into a fragrant fruit,
Tam and Chan Tha turn back into humans, meet the king again and are welcomed to the palace to live happily.

The motif of the incarnation brings the conflict between her stepmother and her husband to a climax, requiring conflicts to be resolved. The incarnation of the unfortunate characters is only temporary because each incarnation, the character only exists for a short time. The transformed forms have no ability to withstand evil deeds, so they are easily destroyed and they continue to transform into other forms. Orphan characters incarnate in many different forms, but whether incarnations in the form of animals, trees or different fruits are human in nature and always follow the lives of relatives. Although Tam is incarnated many times, she is always with her husband. When she transforms into the oriole, she always hangs around the king's palace, gets into the king's sleeves and reminds how to hang clothes. When transforming into the Bead tree, she lull her husband to sleep under her shade. The mother of Chan Tha after dying turns into the golden turtle and the Bodhi tree to be always with her daughter, helping her in life and bringing happiness to her. Chan Tha after dying turns into the Mactum fruit in royal garden to be around her husband and children. All incarnations of the orphan characters are still human in nature, giving signs of life, signaling the return of the orphan characters. After going through many incarnations, the orphan characters are revived and returned to reunite with his family. The motif of the incarnation is to extend the life of the people with imagination and the tragedy of life is replaced by the magical element of fairy tales.

The reincarnation motif in Tam and Cam and the Golden Turtle reflects the traditional beliefs in the lives of the people here. People here believe that when people die, the soul will always be close to relatives to help and protect their family members. This is the basis of the totem worship, each clan worships a totem, that totem may be a plant but usually an animal (Dinh, 1968, p. 37) and the ancestor worship of the people of Vietnam 
and Laos. Therefore, the different transformed shapes of the characters of Tam and Chan Tha are the trees and animals familiar in the lives of the people here. Besides, the incarnation motif also absorbs the philosophy of "reincarnation" of Buddhism and is directed towards goodness, clearly reflecting the theory of "cause - effect" in fairy tales. Orphan characters are people with good qualities and filial piety, so they deserve the help of magical forces to be happy. After many incarnations, they are reborn to the more beautiful human form than before and live happily with their husbands. However, after many reincarnations with many different incarnations, Tam and Chan Tha do not seek happiness in the world of nirvana but struggle to regain the happy life in earthly life. The incarnation motif is a different way of counteracting injustice and inhumanity in society and expressing the dreams, optimism and the thinking nature of the working people when creating a magical fairy tale.

\section{Similarities in unique object motif}

The unique object motif is one of the familiar motifs in the magical fairy tales of the world to help the character find happiness. The unique object in fairy tales is the brokerage object between the girl and the boy and brings happiness to the girl (Dinh, 1968, p. 45). In Tam and Cam, the unique object is shoes given to Tam by a supernatural power, Buddha to go to the festival. The shoes are the predestined object that creates a romantic meeting, the one that connects Tam's happiness with the king. The predestined object in the Golden Turtle is a Bodhi tree turned out from a mother of Chan Tha. The Bodhi Tree with sounds like the singing and playing of fairies becomes a predestined object between Chan Tha and the king. However, the unique object that connects Tam and Chan Tha is the image of betel. This betel nut motif originates from the practice of chewing betel, sawing teeth and staining black teeth of residents of Vietnam and Laos in particular and residents of Southeast Asian countries in general. In the life of the people here, betel nut is a familiar image in everyday life, betel nut is not only a predestined object but also associated with many different customs and traditions, which have a great significance in the practice of traditional beliefs and in social activities. Images of betel pieces show the ingenuity and cleverness of the one forming the betel nuts. Therefore, the betel nut motif in Tam and Cam and the Golden Turtle helps the king to realize that his beloved wife is still alive and to take her back to the palace.

\section{Similarities in magical force motif}

An orphan character who overcomes difficulties, challenges in life and reaches happiness always needs the help of magical forces. It is Buddha's help to Tam and the help of the mother's soul for Chan Tha. Therefore, a magical force is always used in Vietnamese and Lao magical fairy tales. This is an indispensable motif in the process of achieving happiness, turning from zero to having of the little and poor people. This shows the concept "a good turn is never lost" and the desire for a fair and happy life of the working people. "Human memory quickly forgets purely historical fact and must be reinforced by faith. Faith alone leaves an indelible imprint on tradition ... that makes possible its survival, even when the faith itself has long since disappeared" (Taylor, 1964, p. 115).

\section{Differences between Vietnamese culture and Lao culture through the motif of building orphan characters in the magical fairy tales}

Most of the magical fairy tales have similarities in structure and artistic motif, but they differ in the details and the evolution of the details. Through the evolution of the plot in the story, it shows the unique characteristics of each nation. Because the artistic details are derived from the life, customs, religious characteristics, artistic tastes of the nation, "a folk tale provides not only entertainment for the reader but also informs him or her about the culture, customs, history, and everyday life of a people" (Roisin, 1992). Understanding the details of fairy tales is 
the way to explore the unique cultural identity of each nation. That culture, though containing the common regional characteristics, expresses the aspirations and dreams of the masses but is still unique to each country. "These folktales help us to have insight into our own past. We may find information from all kinds of sciences hidden in the folktales such as history, sociology, tribal studies, cultural studies or literary studies" (Ministry of Information and Culture, 1986, p. 1). The motif of building an orphan character in the magical fairy tales of Tam and Cam and the Golden Turtle has many similarities but there are also differences, that difference is most evident in story situations and artistic details in the magical force motif, using the magic elements.

\section{Differences in the circumstances of the story}

In the fairy tale, there are two lines of the hero and the villain, these two lines are always confronted and fought against each other in a strong and fierce manner. Within the family, that relationship is concretized into the relationship between stepchild and stepmother. The magical fairy tales of Tam and Cam and the Golden Turtle touch the hearts of people by the unhappiness and sympathy for Tam and Chan Tha in the uncompromising struggle for happiness. The misfortune of two orphan girls starts from the appearance of her stepmother. The stepmother appears in the Golden Turtle story because the couple has no children, the husband gets a second wife and this second wife is transformed from a demon. The stepmother appears in the story of Tam and Cam because Tam's mother dies, her father marries again and this woman is extremely cruel and sinister. In the struggle for happiness, Tam and Chan Tha represent the Good, which is always confronted with the Evil, the stepmother and the younger sister. In that confrontation, Chan Tha is always loved and protected by a mother beside but Tam is alone in the uncompromising fight with the enemy. The presence of stepmother characters in the fairy tales of Tam and Cam and the Golden Turtle reflects the differences in the process of class and family differentiation in
Vietnam and Laos.

\section{Differences in magical force motif}

The magical force in fairy tales is one of the foundations of the beautiful image of the story. Magical objects and magical forces are elements that folk authors use to solve problems that the actual old social life does not allow to solve according to the wishes of the people (Dinh, 1968). The magic element is not only a means to fulfill the aspirations of the people, but also acts as a cultural code containing the thoughts, emotions, human philosophies and cultural characteristics of each nation. In the story "the Golden Turtle", the magical force is the soul of the mother who turned into a golden turtle to bring fragrance to Chan Tha's hair and body. This incarnation is the memory of a totem with the concept that all things have a soul in the original communal regime. This transformation detail reflects the indigenous beliefs of the Lao people. The totem worship belief is also the basis of the ancestor worship belief of the Lao people and some countries in Southeast Asia. The details that the mother transforms into a Bodhi tree to help Chan Tha become queen bring a profound religious significance. Bodhi tree is a plant with a sacred meaning in Buddhism to the peoples of Southeast Asia. According to the Buddha, the Bodhi tree is the place where Buddha sits in meditation and gradually enlightens the teachings of Buddhism. After enlightenment, Buddha goes everywhere to spread the teachings and guide people to Buddhism. Therefore, the Bodhi tree symbolizes the wisdom and enlightenment of Buddha. For the people of Laos, the Bodhi tree is a happy tree, symbolizing luck and the Bodhi tree is grown in many temples in Laos. The motif of incarnation of the mother into a Bodhi tree to bring happiness to her daughter is also the only motif that brings happiness in the story of the Golden Turtle. Besides, the details that Chan Tha together with the Bodhi Tree mixed with the sounds of joy emanating from the branches of the Bodhi, and the drums and gongs of the delegation reflecting the event of founding Lan 
Xang state, when the King Pha Ngum asks the King Khome to send twenty-three monks and scholars to bring Buddha statues, scriptures, books and Bodhi trees to Laos (Tuyet, 1981, p. 16). The image of the golden turtle and the Bodhi tree in the magical fairy tale of the Golden Turtle shows the outstanding features of Lao culture, which is the harmony between folk beliefs and Buddhist thought in the lives of the people here.

In the magical fairy tale of Tam and Cam, the magic force that brings happiness to Tam is Buddha. Buddha helps Tam have goby to make friends and give her nice clothes to go to the festival. Buddha in the magical fairy tale originated from the Buddha but is popularized to be close to the people. When acquiring Buddhist teachings, Vietnamese people often take simple teachings with little regard for sublime philosophies. Perhaps the most lingering thing of Buddhism in the soul of Vietnam is the generosity and kindness, though not strong in thinking but significant in terms of affection. The Buddha image in Vietnam must have a thousand eyes and a thousand hands, because the eyes are for awareness and the hands are for action. That is the Buddha in the sense of the Vietnamese people (Institute of Philosophy, 1986, p. 147). In the minds of the people here, Buddha is the savior of the world, giving goodness and boundless power to people. Therefore, the Buddha image in folk tales is concretized as the image of a benevolent Buddha, the embodiment of goodness with many miracles to help those who are gentle, suffer a lot and help them achieve fairness and happiness. In addition, the supporting character is the animal that helps Tam, such as a chicken helps her find the bones of goby fish in the pile of kitchen ash to bury at the foot of the bed like instructions of Buddha, the sparrows pick up rice to help Tam go to the festival and detail of the incarnation of the character into an oriole reflects traditional customs and beliefs in the life of Vietnamese people. These are animals which are gentle, familiar and close to the people of Vietnam. In the worship of totem of Vietnamese people, the worship of bird spirit is strongly reflected in folk tales. The Vietnamese believe that their ancestor is a god bird (mother Au Co) and the image of a god bird associated with the worship of the Sun appears on the bronze drum pattern of Vietnamese people. Therefore, the motif of transforming into a bird shows the closeness, intimacy and attachment between humans and nature. Details that Buddha advises Tam to bury the goby bone 100 days reflects the customs and practices of funeral beliefs in the life cycle beliefs of the Vietnamese people. The folk authors let Tam fight to find happiness again in this life and she lives happily on earthly life. Thus, in the cultural life of Vietnam, Buddhism integrates into the social community, the teachings of Buddhism are absorbed by the people here, highly practical, in harmony with traditional beliefs of the nation to form a spiritual and cultural part, contributing to the rich national cultural identity.

\section{Differences in using the magic elements}

The magical element of the story embodied in the incarnation motif of the orphan character shows the spirit of resistance, the uncompromising struggle between the Good and the Evil and the philosophy of life of the working people in each nation. Chan Tha in the story of the Golden Turtle suffers many misfortunes but is always shared by her mother and she only experienced once transformed into a fragrant tree and then returned to being a human and having a happy life. In the struggle for happiness, the kindness and patience of Chan Tha do not change, and her spirit of protest and struggle is not strong. She does not act on her own to regain her happiness but has to rely on the help of other forces. The Evil in the Golden Turtle is punished thanks to the discontent, the wisdom of society (the father and stepmother are abandoned and alienated by the village, the younger sister is punished by the king) and the heart of the heaven and earth (the cracked ground forced the stepmother and aunt to go to hell). In the story of Tam and Cam, Tam has to undergo four incarnations (the Oriole, the Bead tree, the Loom, the Thi tree) showing the conflict between Tam and his stepmother, and the 
younger sister is very fierce, suffering followed her through transformations in various forms. In the struggle to regain life and happiness, the image of Tam has a sharp change from weakness, passive to resolute struggle. Tam is gentle, weak, patient, and accepted her unfortunate fate, accepted oppression of exploitation, injustice and looked forward to the help of Buddha. However, when the conflict is pushed to the climax, her stepmother's act of cutting down trees to kill Tam makes her realize that she has to be strong and fiercely struggling to regain her life and happiness. In that struggle, Tam is alone and did not need any help from the forces. The different incarnations in the form of familiar plants, gentle and friendly animals in life but the vitality of Tam cannot be destroyed by any force. Tam transforms into a Oriole, a Bead tree, a Loom, and a Thi tree, but she still speaks his voice, signaling the presence of her always declaring war on the enemy: Washing my husband's clothes cleanly, drying my husband's clothes with a pole, not drying on the fence, tearing my husband's clothes (Nguyen, 1975). Tam's many incarnations show the vitality, the spirit of resistance, the increasingly fierce struggle, the increasing vigor of people before the destruction of the wicked and the eternal vitality of the Good. Tam is the embodiment of the Good, the stepmother represents the evil, the cruelty and the details of the punishment of the younger sister (Cam), the death of the stepmother is in the name of the Good to destroy the Evil. That not only expresses the desire for happiness and justice but also expresses the conception, philosophy of life of the working people. It is only death that can stop the evil deeds of wicked people and in the uncompromising struggle between good and evil, evil must be destroyed to the end.

Differences in the motif of building orphan characters in the magical fairy tales of Vietnam and Laos due to cultural features arising from the differences in geography, history and cultural components in the development of social structure. Laos is a country deeply influenced by Buddhist ideology, the teachings of Buddhism become the ideology in society and the governing idea in many folklore works. In the magical fairy tale of Laos, conflicts and contradictions of class struggle are not as strong as in Vietnam. Meanwhile, Vietnam is a country deeply influenced by Chinese culture and the ideas of Buddhism, Taoism and Confucianism affect the spiritual life and customs of Vietnamese people. Vietnamese society in the feudal period has a very clear class differentiation and that explains why the contradictions and class struggles in Vietnamese fairy tales are often stronger and more intense compared to magical fairy tales of Laos.

The conflict between orphan characters and stepmother is a common family conflict in fairy tales, and this is a big topic of fairy tales. The orphan's victory to have the happy life proves the philosophy of the Good winning the Evil. At the same time, it shows the concepts "a good turn is never lost", "the evil begets evil" and the good way of life and expresses the aspiration for freedom, equality, happiness and national spirit of the people of Vietnam and Laos. Through the transformations of the orphan characters, the folk author wants to affirm that good is never surrendered, righteousness never surrenders, goodness will fight to the end to protect reason and justice. That is the most important cause of victory. The stories of Tam and Cam and the Golden Turtle are widely circulated and have long-lasting vitality because they reflect the ethical tradition of each nation, the good is always appreciated, upheld and the evil is always condemned and hated. That is the truth for every human action and deed towards. In the fight between good and evil, the victory of good over evil reflects the people's conception: Victory goes from weak to strong reactions and from passive pressure to proactive protests.

\section{CONCLUSION}

The similarity of natural conditions, geographical space and climate of the region creates a close unity of culture, folklore of Southeast Asian countries. 
In particular, the two countries Vietnam and Laos have many similarities when building orphan characters in magical fairy tales. They are poor, unfortunate but good quality, kind, selfless, hardworking characters and they represent Beauty and Good. In the uncompromising struggle with the Evil, the orphan character always wins, attains a happy life and the Evil is punished and destroyed. This is the desire for freedom, equality and happiness of the masses. Therefore, the magic element is used through some basic motifs such as the incarnation motif, the unique object motif, the miracle force motif. However, the motif of building orphan characters shown in the details, the artistic details and the degree of conflict between the orphan character and the hostile forces expresses imprint, cultural and literary identity of each nation. Folk authors when depicting the beauty, qualities and characteristics of orphan characters show the psychological characteristics and aesthetic tastes of each nation. In the motifs of incarnation and use of magical forces in magical fairy tales with different colors reflect the different senses of the people here. The magic element is not only a means to realize the small dreams of the people but also a cultural code containing the thoughts, philosophy of life and cultural characteristics of each nation. Fairy tales are the places where people send their dreams and aspirations in life. One of the many dreams that people dream of is that the good wins evil. Tam and Cam and the Golden Turtle are fairy tales that represent the aspiration of the people of Vietnam and Laos. These are fairy tales that have been born since time immemorial in the history of the nation, exist to this day and will be accompanied go in parallel in the future and will be preserved and handed down by the people of Vietnam and Laos to each other like the ancients keep the fire and spread the fire through each house. It is the traditional fire of the nation that loves the good and hates evil, praises the eternal vitality, the strong rise of man and the good in the struggle with evil to win glorious victories and at the same time shows the belief of the working people in justice and just cause.

\section{REFERENCES}

1. Cao, H. D. (1974). Understanding of Vietnamese folklore process, Social Sciences Publishing House, Hanoi.

2. Dao, V. T. \& Que, L. (1986). Lao Ancient Tales, Ethnic Culture Publishing House, Hanoi.

3. Dinh, G. K. (1968). Preliminary study on the issues of fairy tales through Tam and Cam story, Culture Publishing House, Hanoi.

4. Duc, N. (1999). Literature of Southeast Asia, National University Publishing House, Hanoi.

5. Institute of Philosophy. (1986). Issues on Buddhism and Vietnamese History of History, Social Sciences Publishing House, Hanoi.

6. Lai, P. H. (2004). Similarities and differences in some types of folk tales in Laos and Vietnam, Social Sciences Publishing House, Hanoi.

7. Le, C. Q. (2001). Vietnamese folklore literature, National University Publishing House, Hanoi.

8. Luu, D, T. \& Dinh, V. A. (1989). Indian, Lao, Cambodian Literature, Education Publishing House, Hanoi.

9. Lisevich, I. S. (1978). Литературная m.ysl 'kitaia на рубеже древности я srednikh веков [Literary thought of China from late antiquity to the Middle Ages] (1st ed.). Moscow, Russia: Nauka.

10. Meletinsky, E. M. (2000). The poetics of myth (G. Lanoue \& A. Sadetsky, Trans.). New York: Routledge.

11. Ministry of Information and Culture. (1986). Hom Nithan Phuenmuang Lao lem 1 (Collected Lao Folktales, volume 1) Vientiane: The National Research Institute of Lao Art and Culture.

12. Ngo, V. D. (1995). ASEAN - Cultural Similarities, The Journal of Vietnam and Southeast Asia today, No. 1, $37-42$.

13. Nguyen, D. C. (1975). Treasure of Vietnamese fairy tales, Social Sciences Publishing House, Hanoi.

14. Nguyen, V. D. (2006). Methodology for Literature Research, Social Sciences Publishing House, 
Hanoi.

15. Nguyen, V. D. (2011). Comparative Literary Theory, Social Sciences Publishing House, Hanoi.

16. Nguyen, H. H. (1993). Vietnam - Southeast Asia - Cultural and Historical Relations, Southeast Asia Research Journal No. 4, 107 - 108.

17. Nguyen, V. V. (2005). Folklore literature of Laos, Labor Publishing House, Hanoi.

18. Nguyen, T. K. N. (2017). Folklore and Fantasy Short Stories in Medieval Literature of Vietnam: Otherworld Journeys, Asia-Pacific Social Science Review (2017) 17(1): 112-120.

19. Nguyen, X. L. (1998). Vietnamese folklore literature in the school, Education Publishing House, Hanoi.

20. Propp, V. (1968). Morphology of the folktale (L. Scott, Trans.). Bloomington: Indiana University Press.

21. Que, L., Ngo, V. D., Nguyen, D. N. \& Nguyen, H. H. (1985) Understanding Lao culture, Culture Publishing House, Hanoi.

22. Roisin, O. B. and Thavisack, P. (1992). The Great Gourd Of Heaven: A Selection of the Folk-tales and Stories of Laos, Vientiane: Vannasin Magazine, The Ministry of Information and Culture, np.

23. Sullivan, C. W., III. (2001). Folklore and fantastic literature. Western Folklore, 60(4), 279-296. doi:10.2307/1500409.

24. Tang, K. N. (1994). Magical fairy tale of Vietnamese people - the characteristics of plot structure, Social Sciences Publishing House, Hanoi.

25. Taylor, A. (1964). The biographical pattern in traditionaI narrative. Journal of the Folklore Institute, 1(1/2), 114-129. doi:10.2307/3814034.

26. Thompson, S. (1958). Motif-index of folk-literature: A classification of narrative elements in folktale, ballads, myths, fables, medieval, romances, exempla, and local legends (rev. ed.). Bloomington: Indiana University Press.

27. Tuyet, P., Dinh, K. C. \& Vo, Q. N. (1981). Anthology of Lao literature, Literature Publishing House, Hanoi. 